\title{
ULISSES NO INFERNO DA DIVINA COMÉDIA - UMA COMPARAÇÃO DO HERÓI EM DANTE, HOMERO E VIRGÍLIO
}

\author{
Alysson Ramos Artuso
}

\begin{abstract}
RESUMO
Ulisses é um personagem constante na literatura ocidental e Dante Alighieri foi um dos autores que o retrabalharam. Na Divina Comédia, Ulisses está na oitava vala do oitavo círculo do Inferno, correspondente aos fraudadores. Na construçáo do personagem, Dante retoma características de Ulisses da tradição grega e latina, o que é analisado e comparado nesse artigo a partir das elaboraçōes de Homero e Virgílio. Ao fim, estabelece-se uma relação entre Ulisses e os Dantes - autor e personagem da Comédia.
\end{abstract}

PALAVRAS-CHAVE: literatura comparada; Divina Comédia; Ulisses.

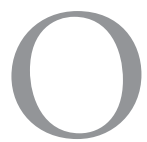

mito de Odisseu/Ulisses é amplamente retomado e retrabalhado pela tradição literária. Entre tantos exemplos, está Dante Alighieri, que trata do personagem na Divina Comédia no Canto XXVI do Inferno. O Ulisses do poeta florentino retoma elementos das épicas homéricas, mas também, e principalmente, da tradição latina. Nesse trabalho, pretende-se comparar e contrastar características do Odisseu de Homero, do Ulisses de Virgílio e do Ulisses de Dante. Confronta-se, ainda, o personagem de Ulisses na Divina Comédia com o próprio Dante personagem, de modo a argumentar que o herói grego serve, em certa medida, como um alter ego de Dante.

A Divina Comédia, escrita no início do século XIV, destaca-se na literatura italiana e mundial por uma série de motivos, entre eles a erudição, pers- 
picácia, complexidade, concisão e concentração de sentidos e significados que Dante Alighieri impôs aos sonoros e ritmados versos de sua obra. Nela, abarca não apenas o quadro histórico em que viveu como também combina elementos de seu tempo "com outros que remetem ao que já passou (ao que, na realidade, não para de passar) e outros ainda que remetem, como antecipação ou vaticínio, ao que está por vir (o que nos inclui, leitores tardios)." (STERZI, 2008 , p. 50). Suas referências e sua precisão vocabular se destacam tanto pela capacidade ímpar de construção de imagens e caracterização de personagens como pelas múltiplas possibilidades interpretativas que permite: literal, alegórica, moral e anagógica, o que lhe coloca ao menos ombro a ombro com os poetas mais renomados da história da literatura ocidental, incluindo os próprios Homero e Virgílio (TOSTO, 1962; BORGES, 1987; ELIOT, 1989; BLOOM, 1995; STERZI, 2008).

Pois será justamente sobre como esses dois poetas citados construíram o personagem de Odisseu/Ulisses ${ }^{1}$ que trataremos a seguir. Antes, de modo a guiar e justificar a análise, cabe colocar a inscrição délfica "conhece-te a ti mesmo" ou, no diálogo entre Alcebíades e Sócrates, contado por Platão (PLATO, 1999, p. 51-2), a ideia de que para a alma conhecer a si mesma deve olhar para outra alma, no sentido de olhar para algo semelhante e nele ver a si própria. Esse diálogo, que trata da alteridade e do autoconhecimento, é aqui estendido para se pensar a construção dos personagens literários: ao se olhar para alguns dos diversos Ulisses que antecederam ao de Dante, busca-se encontrar elementos e reflexos que aumentem o conhecimento do Ulisses do poeta florentino. Mais do que isso, no contraste com Ulisses será possível compreender melhor o próprio Dante.

\section{Odisseu na Ilíada}

Na Ilíada, cuja consolidação escrita data por volta do século VIII a.C., Odisseu é um dos chefes gregos durante os 10 anos da guerra de Troia. Embora a história tenha outros personagens como mais centrais, Odisseu não é apenas um coadjuvante, sendo nomeado por Agamenon, junto com Aquiles e Ajax,

1 Ao se tratar do personagem nas obras homéricas, preferiu-se manter o nome da tradição grega de Odisseu. Na discussáo de Virgílio e Dante, manteve-se o nome Ulisses da tradição latina. 
como um dos três heróis gregos mais temíveis (Canto I, v. 138). Sua primeira aparição relevante se dá no Canto II, após o desentendimento entre Aquiles e Agamenon que faz o Pelida se retirar do combate e sua mãe, Tétis, pedir a Zeus que os gregos percam a guerra. Disposto a atender o pedido de Tétis, Zeus envia a Agamenon um sonho enganoso de que ele venceria Troia e que, portanto, era para as tropas irem para o combate. De modo a testar seus guerreiros, Agamenon os comunica do contrário de suas intenções (assim como Zeus fez com o próprio general argivo): manda-os levantarem o acampamento e voltarem para casa. Evidenciando o quanto o chefe maior dos gregos pode ser desastroso em sua liderança, ao contrário de Zeus, as tropas não tomam a iniciativa de se insuflar para permanecer na guerra, mas começam os preparativos para retornarem para casa. É Odisseu, inspirado por Atena, sua protetora, que incita os soldados, junto com Nestor, a honrarem seus postos de guerreiros e se prepararem para a batalha. Trata-se de uma primeira indicação da capacidade de convencimento de Odisseu, que usa de sua retórica, mas também de intimidaçóes físicas, como com Tersites (v. 246-269), para obter seu intento.

Outra passagem de interesse está no Canto III, quando Príamo observa os argivos das muralhas de Troia e pergunta para Helena sobre os heróis gregos. Ao indagar sobre um de estatura menor, ouve o seguinte de Helena: "Esse é Odisseu, de Laertes nascido, astucioso guerreiro, / [...] / em toda sorte de ardis entendido e varão prudentíssimo” (HOMERO, 2009a, p. 109). Em seguida, o experiente Antenor também conta a Príamo de quando recebeu Odisseu, junto com Menelau, como embaixador em tratativas diplomáticas anteriores à guerra. Em seu discurso (v. 204-220), ressalta ser Odisseu um orador sem paralelo, claro e conciso, mas também dissimulado. É o início da caracterização de Odisseu como astucioso, dotado de uma inteligência persuasiva, digno de elevados cuidados intelectuais, vista sua capacidade retórica e manipulativa. É o herói dotado da métis, que foi caracterizada por Marcel Détienne e Jean-Pierre Vernant (2008, p. 25) da seguinte maneira:

A métis é uma forma de pensamento, um modo de conhecer; ela implica um conjunto complexo, mas muito coerente, de atitudes mentais, de comportamentos intelectuais que combinam o faro, a sagacidade, a previsão, a sutileza de espírito, o fingimento, o desembaraço, a atenção vigilante, o senso de opor- 
tunidade, habilidades diversas, uma experiência longamente adquirida; ela se aplica a realidades fugazes, móveis, desconcertantes e ambíguas, que náo se prestam nem à medida precisa, nem ao cálculo exato, nem ao raciocínio rigoroso.

No Canto IV, há a retomada da guerra e a revista em que Agamenon distribui elogios e reprovaçôes. A Odisseu, o Atrida faz a acusação de ele se demorar para ir às frentes de batalha, no que é prontamente repreendido com o argumento de que "[...] ante as hostes Troianas o pai de Telêmaco avança / entre os primeiros. Carecem de senso teus ditos sarcásticos." (HOMERO, 2009a, p. 127). Nessa mesma passagem, Homero coloca para Odisseu o epíteto de "guerreiro solerte", enfatizando por um lado o uso de meios ardilosos, quando não desonestos, para conseguir algo, mas também a sabedoria e iniciativa do guerreiro sagaz, diligente, astuto. Se de fato Odisseu é um guerreiro corajoso a ponto de avançar entre os primeiros na guerra é uma questão ambígua na Ilíada. Outro exemplo dessa dubiedade está no Canto XI, no qual é citada a posição da tenda do filho de Laertes como central no acampamento grego. Tal posição pode ser tanto uma escolha para deixar equilibrada a defesa, balanceando o posicionamento dos maiores heróis gregos - a tenda de Ajax está em uma extremidade e a de Aquiles na outra -, como também pode indicar a astúcia de Odisseu em se estabelecer um local que, talvez, fosse menos visado em caso de ataque. Se a indicação de sua coragem para o combate é oscilante, por outro lado, sua capacidade com as palavras é inquestionável, visto que foi capaz de repreender por mais de uma vez o chefe dos gregos e ainda assim não ser censurado por ele. Para efeitos de comparação, Diomedes, o herói seguinte a ser agastado por Agamenon no Canto IV, ouve em silêncio injúria semelhante a proferida contra Odisseu e ainda repreende o filho que tenta defender o orgulho familiar. Nesse sentido, o respeito conquistado por Odisseu pela sua astúcia é tamanho que, no Canto XIV, quando vários dos heróis gregos estão feridos, Agamenon decide fugir e é censurado fortemente por Odisseu. Entre outros impropérios, Odisseu chama Agamenon de covarde e desgraçado, mandando-o calar-se. Ainda assim, é respeitado pelo chefe grego, que volta atrás em sua decisão.

Outra demonstração da sabedoria e da capacidade argumentativa de Odisseu é ter sido escolhido por Nestor, em evento narrado no Canto IX, para integrar a comitiva de convencimento a Aquiles para que o herói retorne à 
guerra. Junto com Fenice, preceptor do Pelida, e Ajax, o maior dos guerreiros após o próprio Aquiles, Odisseu leva presentes e honras para convencer o filho de Tétis. Conhecedor dos ardis de Odisseu, é justamente em frente ao Itacense que Aquiles se senta para a conversa e é dele que houve a enumeração de riquezas e honras que receberia caso abrandasse sua cólera e voltasse ao combate. Odisseu finaliza seu habilidoso discurso apelando ao feito extremamente honroso que Aquiles, e somente ele, seria capaz de executar: derrotar Heitor, o maior de todos os troianos, e assim ser venerado tal qual um deus por toda a eternidade. Contudo, é também a Odisseu que Aquiles primeiro comunica sua posição irredutível, por não perceber nele exatamente o ideal de honra guerreira, mas o uso de todos os subterfúgios possíveis para se obter o que se quer: "Filho de Laertes, de origem divina, Odisseu engenhoso, / [...] / Tal como do Hades as portas, repulsa me causa a pessoa / que na alma esconde o que pensa e outra coisa na voz manifesta” (HOMERO, 2009a, p. 122).

No Canto X, Diomedes e Odisseu vão espionar o acampamento troiano. Agindo sorrateiramente durante a noite, novamente a construção de Odisseu não é a do guerreiro tradicional, mas do engenhoso e, no entanto, disposto a açôes arriscadas. Sua astúcia e coragem são, inclusive, motivos pelos quais Diomedes o escolheu entre outros candidatos para acompanhá-lo na missão (v. 242-248). No caminho para o campo dos inimigos, se deparam com Dolão, teucro que vinha espionar os gregos. Capturam-no e o induzem a falar onde estão acampados os troianos e seus aliados. Embora o embuste não seja explícito, o diálogo de Dolâo, que implora pela vida e oferece tesouros, e Odisseu, que exige saber sobre o posicionamento, os cavalos e as armas troianas, induz Doláo a dar todas as informaçóes que lhe são pedidas achando que poderá escapar da morte. Ao terem obtido as informaçóes que precisavam, Diomedes o mata. Na sequência, os dois heróis gregos tomam de assalto um acampamento, matando uma dúzia de trácios e levando armas e cavalos. Ainda nesse episódio, é preciso notar que o filho de Tideu é quem fica responsável pelo combate com os trácios, enquanto Odisseu rouba os cavalos, divisão de tarefas induzida pelo Itacense em um ardil retórico com o próprio Diomedes. Por saber que ele não manda no Tidida - guerreiro que foi capaz de ferir Ares e Afrodite em batalha - lhe dá a ordem de desatar os cavalos enquanto ele, Odisseu, supostamente cuidaria dos homens. Na continuação de sua fala, é mais gentil em dizer "ou, se quiseres, dos homens se incumbe, deixando-me 
os brutos." (HOMERO, 2009a, p. 249), sugestão aceita por Diomedes, infundido de coragem por Atena.

Mas se até então, na épica, Odisseu não demonstrou tão firmemente sua coragem e suas habilidades como guerreiro, isso ocorrerá no Canto XI, no qual vários heróis gregos são feridos em combate. Encurralado na guerra, "tal como quando rapazes e cães ardorosos / açulam um javali [...]” (HOMERO, 2009a, p. 265), o filho de Laertes instiga medo em seus adversários e mata cinco heróis inimigos antes de ser ferido por Soco, mas mesmo ferido ainda mata o troiano. Outra passagem de suas capacidades físicas se dá no Canto XXII, quando Aquiles organiza jogos em homenagem a Pátroclo: Odisseu vence a competição de corrida contra Diomedes e empata com Ajax na luta. Logo, por mais que sua característica principal seja a métis - a astúcia com que obtém o que deseja -, não se trata de um guerreiro menor, mas um combatente forte e digno, a ponto de se igualar com Ajax e estar, nesse quesito, abaixo somente de Aquiles.

O próprio Odisseu reconhece essa capacidade suprema de Aquiles na força, mas também destaca suas próprias qualidades no Canto XIX: "Ínclito Aquiles Pelida, o mais forte de todos os Dânaos / és mais robusto do que eu e no jogo de lança não pouco / me sobrepujas; contudo te sou superior nos conselhos" (HOMERO, 2009a, p. 438). Odisseu saber usar a palavra, a paciência e a persuasão, como evidenciado em suas conversas com Agamenon e em seus estratagemas de guerra. Aquiles, para servir de contraponto, emprega sua força para resolver suas questôes e, quando não cabe a resolução por parte da violência - como no episódio inicial com Agamenon - sua impaciência e sua falta de habilidade retórica ficam evidentes. A afirmação de Albin Lesky (1995, p. 60) sintetiza essa diferença entre os dois heróis: "uma prudente reflexão [Odisseu] frente a uma nobre imoderação [Aquiles], um hábil espírito de conciliação face a uma brusca aspereza, um prudente cálculo do procedimento mais oportuno, face à corrida precipitada pelo caminho mais curto.”.

\section{Odisseu na Odisseia}

Após os 10 anos da guerra de Troia, Odisseu passa outros 10 anos até conseguir retornar à Ítaca e à família, sendo este fato contado na Odisseia. Por ser praticamente toda a história centrada nesse personagem, náo cabe aqui abordar canto a canto as apariçóes do herói, mas traçar um panorama mais 
geral de sua caracterização, ainda que algumas passagens venham a ser destacadas. Antes, contudo, é preciso distinguir alguns pontos.

O primeiro diz respeito à complexidade do universo da Odisseia frente ao da Ilíada. Em geral, essa complexidade é atribuída à diferença de tempo passada entre o registro escrito das duas obras que chegaram até nós: a Odisseia seria algumas décadas posterior à Ilíada (VIDAL-NAQUET, 2002, p. 25). Comentadores como Aubreton (1968), Lesky (1995), Romilly (2001) e Vidal-Naquet (2002) defendem que houve alteraçóes significativas nesse período, bem como um possível amadurecimento do poeta que consolidou o texto. Entre essas mudanças, cabe citar a maior complexidade do sistema social e político na Odisseia, a posição dos deuses como mais alinhados com a ideia de justiça e com intervençóes mais raras sobre os humanos, um trabalho maior com a psicologia e a potencialidade humana, no sentido de que, em comparaçáo com a Ilíada, há "menos força, mas mais sedução, discrição, meias-tintas, uma psicologia mais matizada” (ROMILLY, 2001, p. 24) na Odisseia.

Um segundo ponto é a colocação de Todorov (2004) de que há dois Odisseus na Odisseia, um que conta os feitos e outro que os vivencia, o que acrescenta mais um eixo interpretativo para a obra:

Há dois Ulisses na Odisseia: um que vive as aventuras, outro que as narra. É difícil dizer qual dos dois é a personagem principal. A própria Atena tem suas dúvidas. "Pobre eterno mentiroso! só tens fome de artimanhas!... Voltas ao país e só pensas, ainda, nos contos de bandidos, nas mentiras caras ao teu coração desde a infância..." Se Ulisses leva tanto tempo a voltar para casa é que este não é seu desejo profundo: seu desejo é o do narrador (quem conta as mentiras de Ulisses, Ulisses ou Homero?). Ora, o narrador deseja narrar. Ulisses não quer voltar a Ítaca para que a história possa continuar. $\mathrm{O}$ tema da Odisseia não é a volta de Ulisses para Ítaca; essa volta é, pelo contrário, a morte da Odisseia, seu fim. O tema da Odisseia são as narrativas que formam a Odisseia, é a própria Odisseia. Eis por que, voltando a seu país, Ulisses não pensa nisso nem se alegra; ele só pensa nos "contos de bandidos e nas mentiras": ele pensa a Odisseia. (TODOROV, 2004, p. 104). 
Esse ponto é especialmente interessante para se discutir uma característica da Divina Comédia que dá sustentação à construção do personagem de Ulisses como um alter ego de Dante. Na Divina Comédia há dois Dantes, o autor da história e o seu personagem principal. Essa duplicidade ganha mais dimensões na obra do autor florentino pelo fato de o Dante autor colocar em palavras do Dante personagem pensamentos e passagens biográficas que o próprio Dante autor experimentou, numa trama ainda mais intricada entre quem conta e quem vive.

Voltando a Odisseu, os primeiros versos da Odisseia trazem todos os elementos que serão problematizados nos 24 cantos. Na obra, é cantado o homem (ándra) que com sua astúcia foi capaz de derrotar Troia, mas que por sua curiosidade, ambição e soberba demorou uma década para retornar para casa. Cabe, ainda, ressaltar que a abertura do poema épico denota a elevada importância de seu protagonista: a derrota troiana é decorrente dos ardis de Odisseu (Canto I, v. 2) - sobretudo como mentor do Cavalo de Troia - e não da força e bravura de Aquiles (NAGY, 1979).

Seu primeiro adjetivo é polútropo, o de muitas dimensões, multifacetado, multiversátil. Segundo Malta (2007, p. 57) há cinco epítetos distintivos utilizados por Homero para se referir a Odisseu com o prefixo polú (muitos/ multi): polúmettis ("multiastuto"), polúphron ("multipensante"), polumékhanos (“multiengenhoso"), polúainos ("multíloquo"), e polútlas (“multitenaz"). Esse herói de muitas faces tem desde o início da épica a sua pluralidade assinalada, assim como a pluralidade das experiências que viveu.

Nessas experiências, foi protegido e auxiliado por Palas Atena, deusa e símbolo da sabedoria, que, ao interceder a favor dele junto a Zeus, tem na resposta do deus superior o reconhecimento de Odisseu como distinto dos demais homens em razão de sua capacidade intelectual e dos sacrifícios que oferece aos deuses (Canto I, v. 64-68). Junto à sua métis somam-se características como a curiosidade, a perspicácia, o autocontrole, a articulação, a prudência, a sutileza, a persuasão, o fingimento, a mentira, a fraude, a ambição e a soberba (NUNES, 2009). É principalmente em razão da última que comete sua maior falha e que atrai a ira de Poseidon. Ao deixar a ilha dos Ciclopes, após escapar e cegar Polifemo, filho do deus dos mares e a quem enganou mentindo sobre o próprio nome, tripudia sobre o ciclope vangloriando-se de seu feito: "Ouve, Ciclope! Se um dia, qualquer dos mortais inquirir-te / sobre a razão vergonho- 
sa de estares com o olho vazado, / dize ter sido o potente Odisseu, eversor de cidades, / que de Laertes é filho e que em Ítaca tem a morada." (HOMERO, 2009b, p. 168). Trata-se de sua hybris, do

sentimento de exagerada autoconfiança, orgulho ou paixão, que incita os heróis da tragédia grega a se revoltarem contra as ordens divinas. Em consequência, cometem uma falha grave [...] que acaba provocando a nêmesis, ou seja, a indignação dos deuses, em resultado da qual conhecem o sparagmos, isto é, a morte ou a desgraça. (MOISÉS, 1974, p. 278).

Vale salientar que a primeira parada de Odisseu e sua tripulação ao deixar Ítaca é para saquear outra cidade, embora tenham acumulado inigualáveis riquezas durante a Guerra de Troia, evidenciando o caráter também ambicioso do herói.

Curioso e explorador, Odisseu lidou com muitos seres mitológicos e deuses em seu retorno para Ítaca: os Letófagos, os Ciclopes, os Lestrigóes, as Sereias, os monstros Cila e Caribde, e também os deuses Éolo, Circe e Calipso. De especial proveito para sua caracterização aos objetivos desse estudo é o episódio das Sereias descrito no Canto XII. Nele, Odisseu pede para ser amarrado ao mastro do navio e não ser solto sob qualquer hipótese, mas protege seus companheiros vedando o ouvido deles com cera para que não ouçam o canto das sereias e não sejam encantados e posteriormente mortos por elas. Nota-se, apesar dessa proteção relativa aos companheiros, o desejo do filho de Laertes de passar por essa experiência de ouvir como é o canto. É o Odisseu sedento por conhecer e experimentar. Nessa sede, ele tipicamente busca proteger os seus (como nesse episódio das sereias, mas também no episódio com Circe ou na questão do gado do deus Hélio); ainda assim há passagens em que o herói grego coloca os seus em perigos para além dos riscos da própria expedição de retorno. É o caso do episódio do ciclope Polifemo, que Odisseu fez questão de conhecer, no qual meia dúzia de companheiros são devorados pelo filho de Poseidon.

Contudo, como atesta Todorov (2004), é preciso ter cautela ao se fiar pelos eventos narrados por Odisseu, como os expostos anteriormente. Isso porque boa parte de suas aventuras são contadas por ele próprio ao Rei Alcí- 
noo dos Feácios. Astuto e conhecido mentiroso, suas histórias podem nunca ter acontecido, sendo apenas parte de um estratagema para sensibilizar o rei e conseguir ajuda em seu retorno para Ítaca.

Outra passagem relevante é a visita de Odisseu ao Hades, narrada no Canto XI. Nessa visita, ele conversa com outros heróis gregos, vê a mãe e consulta o adivinho Tirésias sobre seu futuro. No vaticínio que obtém sobre como se dará sua morte, há uma ambiguidade muito enriquecedora para a comparação com o Ulisses de Dante. A tradução de Carlos Alberto Nunes diz o seguinte: “[...] distante do mar há de a Morte / te surpreender de maneira mui doce e suave, ao te vires / enfraquecido em velhice opulenta e deixares um povo / completamente feliz [...]" (HOMERO, 2009b, p. 193).

Se em um primeiro pode parecer que a morte encontrará Odisseu em terra firme, distante do mar, cabe também pensar que a morte de Odisseu está distante, quando estiver velho, mas que ela pode derivar do mar, no sentido de que "do mar, há de a morte te surpreender". Embora reconhecer essa dupla possibilidade na tradução citada seja forçoso, tendo em vista as opções do próprio tradutor, em grego a dubiedade é clara (FINLEY, 2002) e é assim descrita por Freitas (2008, p. 2):

O verso 134, que contém a predição do adivinho, é ambíguo. A expressão thánatos dè toi eks halos permite uma ambivalência na língua grega. Segundo o Dictionnaire Le Grand Bailly, a preposição eks, quando seguida de genitivo, nesse caso, halós, o genitivo de háls, significa vindo de, partindo de ou fora de (BAILLY, 2000. p. 606). Portanto, a expressão thánatos dè toi eks halós, pode ser traduzida como morte longe do mar ou morte que procede do mar. Cabe-nos esclarecer que háls, em grego antigo, pode significar sal (masculino) ou mar (feminino). Daí muitas traduçôes para o português fazerem uso da expressão mar salino.

Tal controvérsia abre caminho para que Dante construa a sua versão para a morte de Ulisses, que seria proveniente do mar.

Por fim, cabe caracterizar Odisseu na Odisseia como um herói não somente de ideias, mas também de ações. Ele planeja, mas também age. É o 
homem que gosta de enfrentar e solucionar os desafios, sempre auxiliado por sua razão, simbolizada pela proteção de Atena. Ao final, é reconhecido tanto como guerreiro, cuja expressão última é o episódio em que verga o arco diante dos pretendentes incrédulos, quanto como filho, pai e marido, cuja posição valorizada como amante tem como símbolo o episódio do leito, em que ele e Penélope têm a prova final de identidade e fidelidade um do outro. Ao reconhecer a lei de Ítaca e usá-la de forma legítima no massacre dos pretendentes, é também reconhecido pela população (mas não sem questionamentos e com nova intervenção de Atena) como o rei. Assim, Odisseu cumpre seus deveres com a família e a pátria, simbolizando um herói que alcançou a glória e a vida longa por meio também de sua força, mas principalmente em razão de seu intelecto superior.

\section{Ulisses na Eneida}

Na Eneida, escrita no século I a. C., Virgílio toma como base os poemas homéricos para contar a saga de Eneias - herói troiano que tinha como destino chegar à região do Lácio e dar origem ao Império Romano. Rivalizando com o próprio Homero, Virgílio constrói seu poema épico emulando a estrutura da Odisseia (nos seis primeiros cantos) e da Ilíada (nos outros seis), ao mesmo tempo em que combina elementos políticos de seu tempo, cantando indiretamente a Julio César e a Augusto (CONTE, 1986; GRANSDEN, 1984).

As apariçóes de Ulisses na Eneida se concentram nos Livros II e III, em que Eneias narra a Dido o último dia de Troia e a viagem que o trouxe até Cartago. No segundo livro ouve-se a história do Cavalo de Troia pelo lado dos vencidos, sendo Ulisses grande responsável pela queda dos teucros. É o herói grego quem elabora o discurso de Sínon, argivo deixado para trás e que conversa com os troianos acerca do presente. Diz ele tratar-se de um substituto de Paládio, a estátua de Palas Atena roubada por Ulisses e Diomedes e que protegia a cidade de Troia. No discurso do grego, a deusa teria ficado irada com os gregos pelo roubo e os teria castigado, fazendo com que desistissem da guerra e construíssem o cavalo como forma de expiar o sacrilégio cometido.

Essa construção do discurso de Sínon é particularmente elaborada por trazer em seus argumentos outros elementos do mito de Ulisses, como seu disfarce de louco para escapar da guerra de Troia e ficar na companhia da esposa 
e do filho recém-nascido. O disfarce fora descoberto por Palamedes, companheiro de Sínon, tendo, segundo o discurso, Ulisses se vingado de ambos durante a guerra, sendo a própria prisão de Sínon pelos troianos parte desse ato vingativo. A passagem exemplifica, em alto grau, a capacidade retórica e a esperteza de Ulisses, que construiu um discurso convincente aos teucros mesmo com as advertências de Laocoonte e Cassandra, embora tenha contado também com a ajuda dos deuses para calar o sacerdote troiano, matando-o junto com seus filhos. Essa caracterização da inigualável astúcia de Ulisses é atestada também por Marques Jr (2011, p. 13):

A propósito da eloquência astuta de Odisseu/Ulisses, lembremos que um dos episódios marcantes no Livro II da Eneida é a fala de Sínon, o grego que se diz desertor e é aprisionado pelos Troianos. O discurso de Sínon astutamente forjado por Ulisses apresenta grande força persuasiva, pois está todo calcado na verossimilhança. Os fatos que ele narra aconteceram, mas não necessariamente da maneira como ele os apresenta aos Troianos. Além de trazer à tona a advertência de Laocoonte - é assim que Ulisses é conhecido? (Sic notus Ulixes?, verso 44) -, o discurso de Sínon se realiza como um dos exemplos mais marcantes do que é verossimilhança [...]

Outro elemento a se extrair dessa passagem é a simbologia do roubo do Paládio como mais um momento em que Ulisses se apossa da sabedoria, o que lhe permitiu, nessa leitura, arquitetar a trapaça do cavalo. Mas náo só por seus estratagemas Ulisses é descrito na Eneida: ele é um dos heróis que está dentro do cavalo e inicia o ataque à cidade. Assim como em Homero, ao homem das ideias se soma a ação. Tanto que, durante a batalha final no palácio de Príamo e arredores, quando Eneias e seus companheiros estão dispostos a morrer defendendo Troia, Ulisses é um dos combatentes e responsável por ferir Pélias, herói troiano que acompanhava Eneias (Livro II, v. 435-6).

Sob orientação de Afrodite, sua mãe, Eneias se retira da luta e leva consigo sua família. Nessa fuga, perde-se da esposa, Creúsa, e, ao retornar para procurá-la, vê a cidade completamente pilhada, com os tesouros sendo guardados por Ulisses em mais um retrato do valor do grego como guerreiro, por 
ser o designado a proteger o butim, mas que também pode ser associado a sua ambição e talvez mesmo a sua prudência em evitar batalhas além das necessárias, já que, ao proteger o espólio, não participaria de confrontos secundários remanescentes da tomada da cidade.

Assim como Ulisses conta seus feitos para o rei Alcínoo na Odisseia, na Eneida sabemos desses fatos pela narrativa de Eneias à rainha Dido. Uma oposição pertinente a colocada por Virgílio é que, ao contrário de Ulisses, Eneias não centra sua história em seus feitos individuais, mas conta as tragédias e a viagem de seu povo, povo o qual lidera e do qual se originarão os romanos.

Se, em Homero, a maioria dos gregos admirava a astúcia, os ardis e os feitos de Ulisses, em Virgílio ele não é mais um exemplo compatível com a honra troiana/latina. Isso se reflete nos adjetivos e nos epítetos utilizados para descrevê-lo: ímpio, malicioso, mísero, hedonista, cruel, enganador, terrível, artista do crime. Mesmo seu soldado, Aquemênides, encontrado por Eneias na ilha dos Ciclopes, refere-se ao filho de Laertes em termos bastante pejorativos: "Sou natural da ilha de Ítaca e um dos soldados de Ulisses, / o desgraçado, Aquemênides me chamo. [...]" (VIRGÍlLIO, 2014, p. 267). Vê-se, nessa passagem, também o descuido de Ulisses com os seus. Na comparação com Eneias, este seria incapaz de deixar para trás um companheiro por negligência ou por estar focado demais em seus próprios interesses, como fez Ulisses.

Ainda nesse episódio, chama a atenção o fato de Eneias evitar o contato com Polifemo, de quem sente medo (Livro III, v. 666-7), em contraposição à citada ansiedade de Ulisses na Odisseia por tudo querer saber e experimentar e que o leva a pedir hospedagem ao ciclope. Nesse sentido, Eneias seria mais sábio por conhecer limites do que é prudente conhecer e vivenciar, bem como por ter maior precaução com os seus ao não submeter seus companheiros a riscos desnecessários. Na comparação dessa passagem na Odisseia e na Eneida, Teixeira (2006, p. 59) argumenta que:

a alteração de comportamento [de Eneias] face ao modelo homérico [Ulisses], mais do que traduzir a incapacidade de enfrentar a adversidade, traduz, em estreita acomodação da norma estoica que associa prudência a conhecimento, aprendizagem. Neste sentido, a refiguraçáo da funcionalidade dos episódios de natureza aventurosa, em ajuste ao teor da missão eneiádica que, 
mais do que debelar monstros, se revela tributária da fundação de um império, encontra-se estreitamente associada à demonstração de um heroísmo, cuja formulação assenta na aquisição progressiva de conhecimento, quer activo, quer passivo, e na sua demonstração.

O Ulisses de Virgílio, portanto, é um grande guerreiro e estrategista, mas é visto, antes, como uma fraude, um vilão falso, trapaceiro, ardiloso e, ao contrário de Eneias, não é uma referência de heroísmo e não serve de modelo para a tradição latina.

\section{Ulisses na Divina Comédia}

No Canto XXVI do Inferno, o personagem Dante está no oitavo círculo do Inferno, o da fraude, em sua oitava vala, a dos maus conselheiros. Lá, os pecadores estão presos em chamas e em contínuo movimento. Pela Lei do Contrapasso, segundo a qual a pena guarda relação por semelhança ou oposição com o pecado cometido, tem-se que os maus conselheiros, os que fizeram uso da razão para enganar outros, ocultando-lhes a verdade, arderão eternamente cobertos pelo fogo. O primeiro paralelo é que, por terem ocultado a verdade de seus interlocutores, os maus conselheiros fraudulentos estão agora ocultos no interior de suas chamas (IGLESIAS, 2012). Além disso, o fogo e sua luz, que os ocultam, funcionam como alegoria do conhecimento e do intelecto, no qual os pecadores queimam por os terem usado em vão.

E aqui, cabe entendermos alegoria como um enunciado que pode ser válido por si próprio, mas que também contém outro. No sentido de que a alegoria

[...] consiste num discurso que faz entender outro, numa linguagem que oculta outra. Pondo de parte as divergências doutrinárias acerca do conceito preciso que o vocábulo encerra, podemos considerar alegoria toda concretização, por meio de imagens, figuras e pessoas, de ideias, qualidades ou entidades abstratas. $\mathrm{O}$ aspecto material funcionaria como disfarce, dissimulaçấo, ou revestimento, do aspecto moral, ideal ou ficcional. (MOISÉS, 1974, p. 15). 
No verso 52, o Dante personagem questiona Virgílio, que o guia pelo Inferno, sobre uma chama de duas pontas. Como resposta, fica sabendo se tratar de Diomedes e Ulisses, e três dos pecados cometidos pela dupla são listados: "dentro daquela chama se ressente / o logro do cavalo, que foi porta; pra a dos romanos garbosa semente; / e lamenta-se o ardil pelo qual, morta, / Deidâmia ainda por Aquiles chora; / e por Paládio a pena se comporta”. (ALIGHIERI, 1998, p. 177).

Ulisses e Diomedes são heróis que tradicionalmente estão juntos nos mitos gregos e latinos. Em Homero, isso foi citado no episódio de Dolão na Ilíada e, na Eneida, no roubo do Paládio. Entre tantos outros mitos, há a descoberta de Aquiles para que ele participasse da guerra, na qual a dupla se disfarça de comerciantes e viaja até as terras de Licomedes. Havia rumores que Tétis escondera Aquiles disfarçado de mulher na corte de Licomedes para que ele não integrasse a tropa grega à Troia e lá perecesse. Como comerciantes, seus cestos de joias e enfeites atraem a atenção das mulheres, mas, ao fundo de um dos cestos, o pai de Telêmaco esconde algumas armas. Ao avistar e se interessar por elas, Aquiles é revelado. Em algumas das versóes da história, Deidâmia é a mulher de Aquiles, que chora sua partida e posterior morte.

Nessa passagem, portanto, já se observa um Ulisses de Dante construído a partir de elementos de Homero e de Virgílio - a parceria com Diomedes, o estratagema do Cavalo de Troia, o assalto ao templo de Atena em Troia para obter o Paládio -, mas acrescido de outras fontes da tradição greco-latina, como a do disfarce de comerciante para assegurar a ida de Aquiles à guerra.

Ainda nesse trecho, evidenciando a capacidade de concisão e riqueza de sentidos do Dante poeta, cabe observar a trapaça do Cavalo como gênese remota de Roma. Essa é uma fala dita por Virgílio, justamente quem cantou na Eneida as origens dos romanos, e contribui para se caracterizar Eneias e Ulisses como opostos. Eneias - e por extensão o povo troiano/romano - não apenas sobrevive ao ardiloso embuste do grego como o transforma em um feito muito maior: o surgimento do Império Romano. Na concepção cristã de Dante, essa é uma alegoria de como tragédias - no caso, a queda de Troia - podem ser permitidas pela sabedoria divina por terem consequências benéficas no futuro - o estabelecimento do povo de Eneias no Lácio.

Na sequência da passagem, Dante pede ansiosamente a Virgílio para falar com os heróis. Há o desejo explícito do Dante personagem em conhecê-los 
e ouvi-los (v. 65-69). Há a conversa, mas é o guia quem interpela os argivos, os questiona sobre como morreram e recebe a resposta de Ulisses. No texto, o motivo de ser Virgílio a tomar a palavra é um possível desdém com que Dante seria tratado pelos gregos (v. 74-5). Virgílio teria o respeito dos heróis em razão de seus versos (v. 79-82), afinal eles foram personagens também do poeta lombardo; mas é possível pensar em ao menos outras leituras.

A primeira é que, diferente de Virgílio, Dante não lia grego e seu contato com os textos homéricos foi através do latim e das recriaçóes latinas. Hipótese de leitura possível, mas com bases não tão sólidas, afinal a compreensão entre personagens que falam línguas diferentes ocorreu em outros momentos da Divina Comédia. Nessa própria passagem, Dante compreende o que fala Ulisses, mesmo que ele supostamente falasse em grego. Ademais, uma referência no canto seguinte coloca Virgílio como tendo conversado com o herói argivo em dialeto da Lombardia (Canto XXVII, v. 20), que sequer existia na época de Virgílio e demonstra a despreocupação de Dante, coerente com sua época, com anacronismos.

Mas a segunda proposta de leitura, que em certa medida se relaciona com a primeira, é a de Virgílio como o intermediário (e atualizador) da cultura grega para a cultura latina - por isso seu intermédio também nesse diálogo. Ao escrever sua obra com inúmeros heróis mitológicos e tendo o próprio Virgílio como guia, o Dante autor também se coloca como um intermediário e um atualizador, agora da cultura clássica latina para o que viria a ser a cultura italiana da Idade Média. Nisso, é importante lembrar que Dante escreveu a Divina Comédia em língua vulgar e não em latim, o que colocaria sua obra, a princípio, sob esse aspecto da opção linguística, em um patamar muito menor do que obras em latim, como a de Virgílio. Em certo sentido, a arrogância grega pode estar relacionada com esse fato, pois os gregos representados já colocariam a cultura helênica como superior à latina, quem dirá em comparação com a cultura de um poeta de língua vulgar como Dante.

O pedido para o herói narrar aonde foi para morrer também é uma ousadia do Dante autor. Ainda que haja muitas recriaçóes e inovaçóes no mito de Ulisses na Antiguidade e no Medievo, raras são as que tratam de sua morte. Como enfatizado anteriormente, a fala ambígua de Tirésias deixa essa questão em aberto e é dela que Dante se aproveita para elaborar sua versão. 
Em perfeita coerência com o personagem retratado, o poeta florentino deixa que Ulisses conte seus feitos em discurso direto, no qual emula o tom épico de elevada retórica característico do herói argivo. Inclusive, o grego é o primeiro personagem da Divina Comédia que ousa e narra a própria morte (LOMBARDI, 2014). O discurso começa, então, não pelo retorno de Ulisses à sua terra e família, mas justamente pelo seu abandono da pátria e dos familiares:

\section{[...] Quando}

91 decidi que de Circe me afastasse, que um ano me enleou lá por Gaeta, antes que Enéas assim a nomeassse,

94 nem de filho ternura, nem afeta pena do velho pai, nem justo amor que alegraria Penélope dileta,

97 em mim puderam vencer o fervor que me impelia a conhecer o mundo, e dos homens os vícios e o valor;

100 e me atirei ao mar aberto e fundo [...] (ALIGHIERI, 1998, p. 178).

O Ulisses sempre curioso, desejoso de conhecer e experimentar se faz presente, mas com importantes diferenças em relação ao herói homérico. $\mathrm{O}$ Ulisses de Dante, já na apresentação de Virgílio e no início de seu próprio discurso, não se mostra nem o guerreiro retratado na Ilíada e nem o herói do retorno da Odisseia. O primeiro é negado pela ênfase nos meios fraudulentos que empregava e o segundo é anulado por ele sequer mencionar o retorno para Ítaca. Fica em aberto a possibilidade, de após ter retornado à Ítaca, Ulisses ter decidido retornar à ilha de Circe (nomeada como Gaeta por Eneias quando lá passou em eventos narrados na Eneida) e por lá ficar um período. Mas também é possível sustentar que o Ulisses de Dante nunca retornou para a sua pátria, tendo ficado junto de Circe no meio de suas aventuras, sem concluir 
seu nóstos, a viagem de retorno da Odisseia. Assim como na Eneida, em qualquer uma das possibilidades, o Ulisses de Dante é colocado em contraposição a Enéias por não zelar pela sua família e pátria como deveria.

Outra característica é o autocontrole e a paciência. Em vários momentos, o Odisseu de Homero demonstra autocontrole, como na chegada à Ítaca e na aproximação ao castelo, fatos narrados ao longo de metade dos cantos da Odisseia. Nessa chegada, ele se aproxima muito paulatinamente de seu filho, de seu castelo, de seus criados, de sua esposa e de seu pai - contendo-se, após vinte anos sem os ver, para não ser surpreendido por eventos como os que acometeram Agamenon, que ao retornar para casa foi morto pela mulher e pelo amante dela. O Ulisses de Dante não demonstra essas qualidades do Odisseu homérico, que sabe a hora de ser equilibrado e paciente, e boa parte de seus defeitos são destacados ou intensificados a partir da caracterização do Ulisses virgiliano, como o ímpeto incauto e a falta de compromisso com os seus.

Voltando ao poema e ao discurso de Ulisses, a viagem a que se lançam ele e seus companheiros, descritos como velhos e tardos (v. 106), alcança as colunas de Hércules, o Estreito de Gibraltar, limite geográfico imposto pelo filho de Zeus aos homens. Para ultrapassá-lo, o argivo usa o dom de persuasão de suas palavras em sua curta oração (orazion picciola):

112 'Ó irmãos', disse eu, 'que por cem mil, vencidos, perigos alcançastes o Ocidente; a esta vigília de nossos sentidos,

115 tão breve, que nos é remanescente, não queirais recusar esta experiência seguindo o Sol, de um mundo vão de gente.

118 Considerai a vossa procedência: não fostes feitos pra viver quais brutos, mas para buscar virtude e sapiência.'

121 Meus companheiros fiz táo resolutos pra viagem, com tão curta oraçáo, que não seriam mais dela devolutos. (ALIGHIERI, 1998, p. 179). 
A escolha das palavras denota elevado conhecimento da psicologia humana, pois, segundo o próprio Ulisses (v. 121-123), o discurso é capaz de convencer rapidamente aos seus interlocutores. É uma enunciação concisa e objetiva, breve e ao mesmo tempo profunda, bem ao modo do próprio Dante (personagem e autor). Esse é mais um elemento para se defender a construção do Ulisses da Divina Comédia como, em alguma medida, um alter ego de Dante, no sentido de que características do Dante autor e personagem se encontram transferidas ou ressaltadas na construção do personagem de Ulisses. Cabe ainda lembrar a imagem de uma voz que emana de uma chama, em uma construção que combina a puniçáo e a magnificência de seu discurso (BLOOM, 1995, p. 89).

O Ulisses de Dante chama seus companheiros de irmãos, um vocativo nunca usado por Homero ou Virgílio, mas não se mostra tấo prudente com seus companheiros quanto o Odisseu homérico. Com gosto pela aventura e com sua tríade - pensa na tua origem, náo seja como um animal e busque a virtude e o conhecimento - incentiva seus companheiros a almejar mais da vida, mas também desafia imprudentemente os limites permitidos aos humanos, uma vez que seu conselho tem como objetivo levar a si e a seus companheiros para além das colunas de Hércules. Essa imprudência com os seus, que em Homero é atenuada e em Virgílio intensificada, em Dante mais uma vez pende para a construçáo latina.

A viagem de Ulisses e seus companheiros é sempre a Oeste, "seguindo o Sol" (v. 117), "voltando a popa pra a manhâ" (v. 124). Novamente cabe tomar o Sol e sua luz como alegoria do conhecimento - alegoria comum em Dante que vai estender esse entendimento para o conhecimento divino, tomando a luz solar como a luz divina, o conhecimento de Deus (BERGAMINI, 2008). Nas palavras de Auerbach (1997a, p. 164), essa prática da alegoria é uma constante do poeta florentino:

A arte de Dante consiste em tomar as ideias e materializá-las, em dar, a cada uma delas, um corpo, sangue, sinais característicos, furores, suavidade, atormentando-as com táo apaixonada obstinação, a ponto de que tais corpos cheguem a exprimir, com precisão absoluta, a alma deles: as ideias que esses corpos devem representar. Eis o que se há de entender por alegoria. 
Nesse sentido, a viagem de Ulisses narrada na Divina Comédia pode ser entendida em múltiplas dimensôes simultâneas. Trata-se, primeiro, de uma viagem que contraria ou visa subjugar as forças da natureza. Por ir sempre atrás do Sol, por não querer se privar de sua luz, deseja evitar o ciclo do dia e da noite, ser superior à natureza. Vale ainda o alerta de França (2005, p. 34):

Cabe lembrar que a ideia de luz, sobretudo a divina, é o principal referencial simbólico para a noção de razão e sabedoria; e Ulisses, quando a seguiu, contrariou tanto a tradição de sua época - que impôs as barreiras simbolizadas pelas montanhas chamadas colunas de Hércules - quanto os limites naturais, que dosam a quantidade de luz a ser irradiada pelo sol a todos os homens. Portanto, sob o viés dantesco, mereceu a morte, mas levou também consigo os marinheiros que o acompanhavam desde as aventuras narradas na Ilíada e na Odisseia.

No entanto, o desejo de seguir o Sol não basta para os viajantes se manterem sob ele, tanto que as referências utilizadas para localizar a viagem geográfica e temporalmente são referências noturnas: as estrelas (v. 127), a lua (v. 130). $\mathrm{Na}$ cosmologia de Dante, tratam-se de reflexos da luz solar. Em segundo lugar, pode-se pensar em uma necessidade de se buscar a luz celestial, o conhecimento de Deus, mesmo que o grego não tenha consciência dessa dimensão divina. A falta que Ulisses sente e que o faz se aventurar, sob essa ótica, é também uma necessidade de Deus, aspecto que será retomado adiante.

Uma interessante perspectiva para se pensar a viagem do itacense, que ultrapassa as colunas de Hércules, adentra o hemisfério Sul e após cinco meses alcança a montanha mais alta já vista pelos viajantes é a perspectiva cosmológica/ científica. Na Europa da Idade Média, o conhecimento do hemisfério Sul era limitado, e um mapa celeste completo que permitisse a navegação segura por esse hemisfério só seria traçado pelo inglês Edmund Halley no século XVIII. O personagem de Ulisses, no entanto, faz alusão às características do céu nos versos 127 a 129: "Do outro polo as estrelas todas via / agora à noite, enquanto, rebaixado, / do chão do mar o nosso não surgia" (ALIGHIERI, 1998, p. 179). Sobre essa passagem, Longfellow (1867, p. 309) ao comentar a Comédia, cita a descrição de Humboldt quando ele cruzara pela primeira vez para o hemisfério Sul: 
A partir do momento em que entramos na zona equatorial, nós nunca cansamos de admirar, a cada noite, a beleza do céu do Sul, que, conforme avançamos para o sul, abre novas constelações para a nossa vista. A sensação é indescritível, quando, ao nos aproximarmos do Equador e, particularmente, na passagem de um hemisfério para outro, vemos aquelas estrelas, as que temos contemplado desde nossa infância, irem afundando progressivamente, até, finalmente, desaparecerem. Nada desperta no viajante uma lembrança mais viva da imensa distância que ele está de sua terra do que um firmamento desconhecido. Alguns agrupamentos de estrelas muito brilhantes e algumas nebulosas dispersas, rivalizando com o esplendor da Via Láctea, e notáveis faixas de espaço de absoluta escuridão dão uma fisionomia especial ao céu do Sul. Essa vista arrebata até mesmo aqueles sem instrução nos ramos das ciências que ao contemplar a abóbada celeste sentem a mesma sensação de encanto como quando estão diante de uma paisagem esplendorosa ou um local majestoso. Um viajante não precisa ser botânico para reconhecer que está em zona equatorial pelo aspecto da vegetação; e não precisa ter qualquer noção de astronomia, qualquer familiaridade com as cartas celestes de Flamstead e De la Caille, para saber que náo está na Europa quando vê a imensa constelação do Navio ou quando as brilhantes nuvens de Magalhães surgem no horizonte².

2 "From the time we entered the torrid zone, we were never wearied with admiring, every night, the beauty of the Southern sky, which, as we advanced toward the south, opened new constellations to our view. We feel an indescribable sensation, when, on approaching the equator, and particularly on passing from one hemisphere to the other, we see those stars, which we have contemplated from our infancy, progressively sink, and finally disappear. Nothing awakens in the traveler a livelier remembrance of the immense distance by which he is separated from his country, than the aspect of an unknown firmament. The grouping of the stars of the first magnitude, some scattered nebulae, rivaling in splendor the milky way, and tracks of space remarkable for their extreme blackness, give a particular physiognomy to the Southern sky. This sight fills with admiration even those who, uninstructed in the branches of accurate science, feel the same emotion of delight in the contemplation of the heavenly vault, as in the view of a beautiful landscape, or a majestic site. A traveller has no need of being a botanist, to recognize the torrid zone on the mere aspect of its vegetation; 
A viagem, portanto, indica a coragem de Ulisses, mas também pode ser lida como mais uma ultrapassagem de limites do que é permitido aos humanos, com a ideia do Sul sendo uma ideia de fronteira.

Contribui para essa leitura o mito das Ilhas Afortunadas, citado, entre outros, por Hesíodo em "Os Trabalhos e os Dias" e Píndaro na "Ode Olímpica”. Esse mito gerava, na Antiguidade e na Idade Média, especulaçôes sobre o "Mundo Austral" (DUVIOLS, 1992, p. 168). Segundo a tradição, os habitantes dessa ilha eram intocados pela tristeza, encontravam uma natureza generosa, com grãos abundantes e frutos doces, vivendo em fortuna, honra e glória. Para Píndaro, o lugar seria o destino final, de repouso pós morte, das almas mais justas e honradas. Teria sido o destino de Cadmo, fundador mitológico de Tebas, e de Peleu e seu filho Aquiles. Durante a alta Idade Média, "as Ilhas Afortunadas ficaram ligadas à lenda das viagens de São Brandão, o monge irlandês que as teria visitado e nelas teria encontrado o jardim do Éden ou Paraíso Terrestre" (WIKIA, 2015).

Na viagem de Ulisses, ele avista no hemisfério Sul uma alta montanha (v. 133), que, no Universo da Divina Comédia, é a montanha do Purgatório ${ }^{3}$ em cujo cume se encontra o Paraíso Terrestre. $\mathrm{O}$ argivo, contudo, não é capaz de identificar o que avistara e, após navegar três vezes no entorno da montanha, na quarta o mar se fecha sobre ele e seus marujos. Tem-se, então, a cena de morte do filho de Laertes, com o paradoxo de seu "batismo mortal", seu túmulo sendo os mares, em uma imagem que também remete aos enterros; com o mar, em vez da terra, selando a tumba dos mortos. Essa imagem contrasta com outra presente no mesmo canto, a da subida do profeta Elias ao céu em uma carruagem de fogo (v. 34-36). Por um lado, a ascensão pelo fogo daquele que é aceito no plano divino; de outro, o que afunda nas águas por não ter a permissão de acessar esse plano.

Como dito, ao se relatar uma dubiedade na profecia de Tirésias na Odisseia, Dante se aproveita da possibilidade de colocar o termo da vida do herói grego em uma aventura marítima. Também chama a atenção a menção aos

and without having acquired any notions of astronomy, without any acquaintance with the celestial charts of Flamstead and De la Caille, he feels he is not in Europe, when he sees the immense constellation of the Ship, or the phosphorescent clouds of Magellan, arise on the horizon."

3 Referência a esse fato se encontra no primeiro canto do Purgatório, nos versos 130-132. 
quatro elementos aristotélicos na narrativa que envolve Ulisses: é ao avistar a terra, em sua viagem pelo mar, que o navio voando com asas de remos (“já são / asas os nossos remos, na ousadia / do voo"; ALIGHIERI, 1998, 179) é afundado. Às referências aos três elementos presentes na narrativa da morte (terra, água e ar) se soma a presença no Inferno enquanto fogo.

Para Roda (2012) o conselho fraudulento que Ulisses dá a seus companheiros para colocá-los no mar é o motivo dele estar no Inferno:

O mau conselho de Ulisses, que levará a todos à perdição, surge do engano, da não aceitação da condiçáo humana e de uma necessidade de vitória sobre o destino que a todos envolve e conduz à confirmação da mortalidade. Ao insuflar, em seus amigos, a possibilidade de uma conquista que não vai acontecer, Ulisses frauda o sentimento de todos enquanto também procura fraudar ou mascarar a realidade da qual náo podem escapar, uma vez que ele mesmo os descreve como "vecchi e tardi" [velhos e tardos]. (RODA, 2012, p. 124).

Que se trata de um mau conselho, não há dúvida; no entanto, é questionável se há argumentos no texto de Dante para sustentar a proposição de Ulisses ter agido de má fé ao convencer seus companheiros em segui-lo na viagem, como se o heroi soubesse de antemáo que ele e seus companheiros encontrariam a morte. Os elementos encontrados no texto apontam mais o sentido de imprudência de Ulisses, cuja ambição por querer saber cada vez mais o leva à aventura desmedida, mas não lhe dando a percepção (embora fosse prudente desconfiar) de que levaria à ruína a si e a todos os companheiros. E, como motivação para estar no Inferno, não se pode esquecer seus múltiplos pecados de fraude, inclusive os citados explicitamente na Comédia: o cavalo de Troia, o engano a Aquiles e o roubo do Paládio. Mas há ainda mais e defendemos que esteja em sua busca desenfreada pelo conhecimento, e não nas mentiras, nas fraudes ou nos maus conselhos, a mais grave ${ }^{4}$ das faltas do Ulisses dantesco.

4 Cabe ressaltar que os pecadores da Divina Comédia estão nos círculos que, para Dante, melhor os caracterizam, o que náo significa que o pecado desse círculo seja o mais grave entre os cometidos por eles. 
Essa proposição de que a principal falha do herói grego está em sua ambição por querer saber cada vez mais a ponto de seguir permanentemente o Sol/conhecimento não é por outro motivo senão pela busca do conhecimento com fim em si mesmo, sem que importe idade (velhos e tardos, como diz o verso 106) ou limite. Entretanto, o que a Comédia mostra é que há limites para os seres humanos conhecerem. No canto em questão, esse limite está representado pelo Estreito de Gibraltar, as colunas de Hércules.

Retomando o conceito de figura de Auerbach (1997b), no qual uma realidade tem validade por si própria, mas também prefigura outra posterior mais definitiva, a figura pode ser, então, "algo real e histórico que anuncia alguma outra coisa que também é real e histórica. A relação entre os dois eventos é revelada por um acordo de similaridade." (AUERBACH, 1997b, p. 27). E real deve ser entendido dentro do contexto de determinada obra ou mitologia, não é necessariamente uma existência física incontestável. No caso, Hércules é filho de Zeus, o deus supremo da mitologia grega, e representa uma prefiguração de Cristo, filho de Deus. Foi, portanto, Hércules/Cristo quem estabeleceu o limite ultrapassado por Ulisses.

$\mathrm{Na}$ cultura aristotélica, a mente é como um navio, sendo a popa a memória e a proa a imaginação. A viagem naval de Ulisses pode ser entendida como essa alegoria aristotélica radical, na qual se pretendia obter o conhecimento perfeito por meio do intelecto humano, sem a mediação da graça divina e durante a mortalidade terrena. No entanto, tal pretensão se mostrou fracassada.

O desejo de conhecer levado ao extremo, que na tradição antiga era uma característica positiva do herói homérico, se torna, em Dante, pecado por desdenhar os limites da natureza humana. Também mostra a fraqueza do homem, abandonado à sua própria força, sem a orientação teológica da Graça, afinal Ulisses não está atrás de um conhecimento para se aproximar de Deus, sua busca não está alinhada com a fé, tanto que ele nem mesmo reconhece a montanha que avista.

Nessa perspectiva, a perseguição desenfreada de Ulisses por um conhecimento que lhe é proibido é comparável ao Pecado Original. Na tradição bíblica, Deus impôs limites a Adão e Eva: não comer do fruto da Árvore do Conhecimento. Ao fazerem-no, foram punidos, pois ultrapassaram o símbolo de fronteira, a lei que o homem não deve violar: tentaram "ser como Deus, conhecendo o bem e o mal" (Gênesis 3,5). 
Ulisses está justamente atrás de um conhecimento interdito, querendo apreender além do que se deve e cruzar a fronteira do proibido. Fronteira essa que também pode ser entendida em um outro plano como a lei divina da justiça e da boa fé: Ulisses extrapola o que era preciso para sua sobrevivência, exagera no exercício de seu intelecto, usando-o para enganar e manipular os outros, e na ousadia de seus atos quer alcançar o que a nenhum mortal - exceto ao Dante personagem, que visita os reinos divinos - é permitido.

Retomando Aristóteles, cuja influência é central na Divina Comédia, Ulisses extrapola a justa medida por não se comportar com moderação, por não ser capaz de utilizar sua razão para controlar seus impulsos. Pelo contrário: nessa leitura proposta, ele usa sua capacidade intelectual até mesmo para uma aproximação indevida de Deus, querendo se apropriar de um conhecimento vetado aos humanos e, portanto, tentando se igualar a Deus do mesmo modo que Adão e Eva o fizeram ao comer o Fruto Proibido, e que fez o próprio Lúcifer, o que levou à sua queda (FRANÇA, 2005; LOMBARDI, 2014).

Finalizando essa caracterização, é possível elencar alguns aspectos do Ulisses de Dante: é curioso, sedento por conhecer e experimentar; é astuto, o que o levou à fraude; é corajoso, o que o levou à viagem; é um excelente orador, tanto que convenceu rapidamente os companheiros; é um homem de ideias e de ação, mas que erra por colocar seu intelecto a serviço do engano, erra por não ter autocontrole e extrapolar a justa medida, erra por não ter espírito coletivo e nem familiar, não cumprindo seu compromisso por ambos ao não retornar para Ítaca, e erra, por fim, por não ter orientação divina. O resultado, em vida, é a curta alegria (v. 136) e, na morte, a eternidade na oitava vala do oitavo círculo do Inferno, pois, mais do que apenas o limite geográfico (as colunas de Hércules, o Mundo Austral, a Ilha do Purgatório) e o limite moral (o roubo, a trapaça, a fraude), Ulisses ultrapassa os limites de sua própria autonomia como homem diante de Deus, os limites de sua liberdade individual, os limites das possibilidades humanas.

Personagem complexo, mantendo suas tradicionais múltiplas faces, o Ulisses de Dante tem aspectos da grandeza do herói homérico, mas, principalmente, tem os defeitos intensificados do personagem da Eneida. Ainda assim, não é tratado como antítese dos ideais de cavalaria da Idade Média ou dos ideais que o próprio Dante coloca na Divina Comédia. Se por um lado o grego náo retorna para casa ou para a pátria terrena, por outro lado ele chega até os limites da 
Pátria Celeste. O acesso a essa Pátria lhe é negado, mas sua busca pode ser lida, pelo ângulo do Auerbach, como a necessidade que até um pagão sente da esfera divina. Nesse sentido, Ulisses teria a intuição de que existe algo mais, de algo que excede a capacidade humana; é a sua prefiguração da verdade divina, mas que só seria concebível aos humanos pelo sacrifício de Cristo, posterior, portanto ao período do itacense. O rei de Ítaca, de certa forma, quer esse conhecimento para si e, por necessidade da viagem, ele também seria de ciência de seus companheiros, mas a finalidade que o herói argivo daria às experiências vividas e às aprendizagens adquiridas seriam de natureza muito diferente à finalidade do conhecimento obtido pelo Dante personagem, a quem cabe compará-lo.

Assim como Ulisses, o Dante personagem (e aqui essa análise pode ter pontos de encontro também com o Dante autor) apresenta seus momentos de prepotência e audácia ${ }^{5}$. Ele também é reconhecido por sua capacidade argumentativa, sua elevada retórica e seu intelecto superior. Nesse sentido, o Dante personagem pode ter algum temor de acabar como Ulisses, afinal, como o herói grego, sua curiosidade o leva a querer saber cada vez mais e o coloca, ainda que com a razão aliada à fé e à prudência, na loucura (folle no original, desatino na tradução) de uma viagem pelo desconhecido, como afirma o Dante personagem no Canto II do Inferno:

34 Portanto, se a seguir ora me obrigo, temo que um desatino isso seria; és sábio, e mais entendes do que eu digo”.

37 Como quem não quer mais o que queria

se a nova ideia altera a sua proposta

e da primeira todo se desvia,

40 tal fiquei eu naquela escura encosta

Porque, pensando, consumi o intento

ao qual dera táo rápida resposta. (ALIGHERI, 1998, p. 33)

5 Exemplo, entre tantos, é a passagem do Canto IV do Inferno, em que o Dante personagem, acompanhado de Virgílio, encontra Homero, Horácio, Ovídio e Lucano. Nela, Dante autor faz com que os poetas logo aceitem o Dante personagem em seu grupo, tomando-o, no verso 102, como o "sexto entre tanto saber." (ALIGHIERI, 1998, p. 46). 
Os objetivos, contudo, são de natureza diferente: Dante busca conhecer Deus para disseminar ${ }^{6}$ suas experiências para os outros e poder salvá-los, trazendo-os para o caminho divino. Conforme relata Auerbach (1997a), a jornada de Dante é salvar a si e aos outros, pois, na incerteza de seu destino através da floresta escura (que pode ser vista como ligada à sua vida terrena) e ao longo da obra nos reinos do Inferno, Purgatório e Paraíso, "só ele não tem ainda lugar definitivo. Ele é o homem vivo em geral, e todo homem vivo pode identificar-se com ele. O drama humano, o perigo que ameaça todos os viventes" (AUERBACH, 1997a, p. 212).

É também nesse sentido que o Dante personagem tem a necessidade de Virgílio (alegoria da razão) em sua passagem pelo Inferno, um guia que conheça o caminho e náo o deixe se perder novamente. Em certa medida, o Dante autor se coloca justamente como esse guia para o restante da humanidade, indicando que o caminho da salvação passa pelo conhecimento, "que descreve e demonstra a unidade da ordem, que é, ela, o conhecimento supremo" (AUERBACH, 1997a, p. 99).

Colocando entâo como pares de diferenças, Dante é o peregrino, enquanto Ulisses é o explorador; Dante segue um guia, Virgílio e depois Beatriz, Ulisses segue apenas a própria audácia; Dante conta com a razão e a fé, Ulisses é só astúcia, desconhece o plano espiritual; Dante confia na providência divina, Ulisses aposta somente em suas próprias forças; Dante se move verticalmente pelo Inferno, Purgatório e Paraíso, Ulisses realiza sua viagem no plano horizontal da Terra; Dante teve a permissão divina para sua viagem pelo desconhecido dos três reinos, Ulisses não teve acesso ao Purgatório.

O Dante autor foi um teólogo, mas como literário ousou "ler" a mente de Deus; se atreveu a descrever os três reinos, praticamente instaurando o advento do Purgatório (STERZI, 2008); equiparou, de certa forma, Beatriz à Virgem Maria; colocou reis e papas no Inferno, e assim por diante. A audácia de sua aventura literária não foi menos arriscada que a hipotética viagem de Ulisses, não foi menos árdua e poderia até mesmo ser igualmente fatal. O possível conflito mental do próprio Dante autor, cuja ousadia podia ser encarada como sacrilégio, é levado até o canto XVII do Paraíso, onde Cacciaguida dirá ao Dante personagem (v. 130-132) que a voz dele, Dante,

6 E vale ressaltar que é com base na possibilidade de disseminação que o Dante autor também opta por escrever a Comédia em língua vulgar. 
poderá até incomodar em um primeiro momento, mas será o alimento vital quando digerido.

Tivesse Ulisses a consciência ou a reflexão necessária sobre seus atos, veria que eles o levariam ao suicídio, ao final de sua vida; quem sabe Dante, refletindo sobre sua obra, temesse que ela o levasse para um fim similar, com o esquecimento ou a repulsa de seu nome, mas o que pretendia - e obteve - era se eternizar.

Em ambos, Dante e Ulisses, cabe também realçar, além do desejo de transpassar limites, o orgulho. Na análise de Harold Bloom (1995, p. 89),

[...] Ulisses e Dante estão em relação dialética, porque Dante teme a profunda identidade entre ele mesmo como poeta [...] e Ulisses como viajante transgressor. Esse medo pode não ser inteiramente consciente, mas Dante deve senti-lo em algum nível, porque retrata Ulisses como se levado pelo orgulho, e jamais existiu poeta mais orgulhoso que Dante [...].

Bloom (1995) limita sua comparação ao Dante autor, ainda que não elabore detalhadamente seu argumento com elementos embasadores da obra, também em razão da natureza e dos objetivos diversos de seu texto. De todo modo, essa é uma lacuna que se pretendeu preencher no presente artigo.

Com essa exposição, propóe-se mais uma interpretação de porque não fora Dante quem falou diretamente com Ulisses: de certo modo, ele é Ulisses. Seja para escrever a Comédia, seja para percorrer os três reinos, ele teve que desbravar mares e se aventurar, contando com sua audácia, coragem, obstinação e autoconfiança para fazê-lo. No Ulisses de Dante, a busca se dá às custas da família, de não mais retornar para a esposa, o filho ou o pai. Há de argumentar que foram, possivelmente, também o orgulho e a obstinação que fizeram Dante não encurtar ou pôr fim em seu exílio de Florença e retornar para seus amigos e familiares, de quem morrerá afastado. É ainda nesse sentido que cabe mais uma vez retomar Bloom (1995, p. 91):

Comer o pão de sal de outro homem, descer escadas que não são nossas, é um preço que se paga pela busca. Ulisses está disposto a pagar um preço mais final. Que experiência está realmente mais 
próxima de Dante - a triunfante conversão de Santo Agostinho ou a última viagem de Ulisses? Diz a lenda que Dante era apontado nas ruas como o homem que de algum modo voltara de uma viagem ao inferno, como se fosse uma espécie de xamá. Podemos supor que ele acreditava na realidade de suas visóes; um poeta de tal força que se julgava um verdadeiro profeta, não encararia sua descida ao Inferno como simples metáfora. Seu Ulisses fala com absoluta dignidade, e uma terrível pungência: não o pathos de danação, mas o orgulho que sabe que orgulho e coragem não bastam.

Assim, voltando à citação inicial de Platão e à proposta de alter ego, tem-se a construção de Ulisses como um duplo reflexo de Dante, duplo por refletir tanto o autor quanto o personagem. Por meio do herói grego, Dante é capaz de conhecer a si mesmo; por meio do olhar para a outra alma, Dante autor e personagem poderiam ver nela o espelhamento de si próprios. Assim, as características de Ulisses retomadas, entre outros, de Homero e Virgílio, e somadas às criaçóes e recriaçóes da Divina Comédia encontram-se presentes, por semelhança ou oposição, nos próprios Dantes.

\section{Referências}

ALIGHIERI, Dante. Divina Comédia - Inferno. Trad. Italo Eugenio Mauro. São Paulo: 34, 1998.

AUBRETON, Robert. Introdução a Homero. São Paulo: Difel/Edusp, 1968. AUERBACH, Erich. Dante, poeta do mundo secular. Trad. Raul de Sá Barbosa. Rio de Janeiro: Topbooks, 1997a.

. Figura. São Paulo: Ática, 1997b.

- Dante e Virgílio. In: ARRIGUCI JR, Davi; TITAN JR, Samuel (Org.). Ensaios de literatura ocidental. São Paulo: Editora 34, 2007.

BAILLY, Anatole. Le grand Bailly. Dictionnaire Grec-Français. Paris: Hachette, 2000.

BERGAMINI, Kamila Brumatti. A divina originalidade na comédia de Dante: escrita profética para nós, leitores contemporâneos. Revista Eletrônica de Estudos Literários, Vitória, v. 4, n. 4, p. 1-14, 2008. 
BLOOM, Harold. A estranheza de Dante: Ulisses e Beatriz. In: . $O$ cânone ocidental. Rio de Janeiro: Objetiva, 1995. p. 80-106.

BORGES, Jorge Luís. Sobre a Divina Comédia. In: . Sete noites. São Paulo: Max Limonad, 1987. p. 14-42.

BRITO, Emanuel França de. As faces da gula no inferno da Divina Comédia. 2005. 48 f. Monografia (Curso de Letras, Estudos Literários, Italiano) - Setor de Ciências Humanas, Letras e Artes, UFPR, 2005.

CONTE, Gian Biagio. The rhetoric of imitation: genre and poetic memory in Virgil and other Latin poets. Ithaca: Cornell University Press, 1986.

DUVIOLS, Jean Paul. O Terceiro Mundo Austral. In: CHANDEIGNE, Michel (Org.). Lisboa ultramarina 1415-1580: a invenção do mundo pelos navegadores portugueses. Rio de Janeiro: Jorge Zahar, 1992.

ELIOT, T. S. Dante. In: . Ensaios. São Paulo: Art Editora, 1989. p. 63-112.

FREITAS, Tatiana. Da Odisseia ao Finismundo: experiência e vivência em Homero e Haroldo de Campos. In: Congresso Internacional da ABRALIC, 11., 2008, São Paulo. Anais... São Paulo: USP, 2008.

FINLEY, Moses. The world of Odysseus. New York: New York Review of Books, 2002.

GRANSDEN, Karl. Virgil's Iliad. Cambridge: Cambridge University Press, 1984.

HOMERO. Ilíada. Trad. Carlos Alberto Nunes. São Paulo: Ediouro, 2009a. . Odisseia. Trad. Carlos Alberto Nunes. São Paulo: Ediouro, 2009b.

IGLESIAS, Maria Clara. Borges y sus ter interpretaciones del canto de Ulises em el Infierno de Dante. MLN, v. 127, p. 282-301, 2012.

LESKY, Albin. História da literatura grega. Lisboa: Fundação Calouste Gulbenkian, 1995.

LONGFELLOW, Henry W. The Divine Comedy of Dante Alighieri. Trad. Henry Wadsworth Longfellow. Vol. I. Boston: Ticknor and Fields, 1867.

LOMBARDI, Andrea. Haroldo de Campos e a interpretação luciferina. Cadernos de Tradução, Florianópolis, no especial, p. 182-197, jul./dez. 2014.

MALTA, André. Polú pollá pollôn: multiplicidade no proêmio da Odisseia. Synthesis, Pará de Minas, v. 14, p. 53-70, 2007. 
MARNOTO, Rita. O Ulisses de Dante e sua presença na cultura italiana do séc. XX. In: OLIVEIRA, Francisco de (Org.). Penélope e Ulisses. Coimbra: Univ. de Coimbra, 2003. p. 167-196.

MARQUES JR, Milton. Dicionário da Eneida, de Virgílio - Livro II. João Pessoa: UFPB, 2011.

MOISÉS, Massaud. Dicionário de termos literários. São Paulo: Cultrix 1974.

NAGY, Gregory. The best of the Achaeans: Concepts of the Hero in Archaic Greek Poetry. Baltimore: Johns Hopkins University Press, 1979.

NUNES, Carlos Alberto. Prefácio. In: HOMERO. Odisseia. Trad. Carlos Alberto Nunes. São Paulo: Ediouro, 2009.

PLATO. Alcebiades I. Trad. Benjamin Jowett. Champaign: Project Gutenberg, 1999.

RODA, Regiane Rafaela. Mitologia dantesca: a referência aos mitos greco-romanos na Divina Comédia pelo viés da (re)criação poética de Dante Alighieri. 2012. 169 f. Dissertação (Mestrado em Letras) - Pós-Graduação em Letras do Instituto de Biociências, Letras e Ciências Exatas, UNESP, 2012.

ROMILLY, Jacqueline De. Homero: introdução aos poemas homéricos. Lisboa: edições 70, 2001.

STERZI, Eduardo. Por que ler Dante. Rio de Janeiro: Globo, 2008.

TEIXEIRA, Cláudia A. A. O heroísmo na Eneida - alguns aspectos da formação e evolução de Eneias. Humanitas, Coimbra, v. 58, p. 53-67, 2006.

TOSTO, Rosário. História da literatura italiana. Rio de Janeiro: Vozes, 1962. VIDAL-NAQUET, Pierre. O mundo de Homero. São Paulo: Companhia das Letras, 2002.

VIRGílLIO. Eneida. Trad. Carlos Alberto Nunes. São Paulo: 34, 2014.

TODOROV, Tzvetan. As estruturas narrativas. São Paulo: Perspectiva, 2004.

WIKIA. Ilhas Afortunadas. Disponível em: <http://pt.fantasia.wikia.com/ wiki/Ilhas_Afortunadas>. Acesso em 13 dez. 2015. 


\title{
ULYSSES IN THE DIVINE COMEDY - HELL - A COMPARISON OF THW HERO IN DANTE, HOMER AND VIRGIL
}

\begin{abstract}
Ulysses is a constant character in Western literature and Dante Alighieri was an author that rework him. In the Divine Comedy, Ulysses is in Hell, in the eighth ditch of the eighth circle, corresponding to the fraudsters. In the construction of this character, Dante recovered Ulysses characteristics from Greek and Latin tradition, which is analyzed and compared in this article with the Homer's and Virgil's characters. At the end, Ulysses and Dantes - author and character of Comedy - are related.

KEYWORDS: comparative literature; Divine Comedy; Ulysses.
\end{abstract}

Recebido em: 05/01/2015

Aprovado em: 18/03/2016 